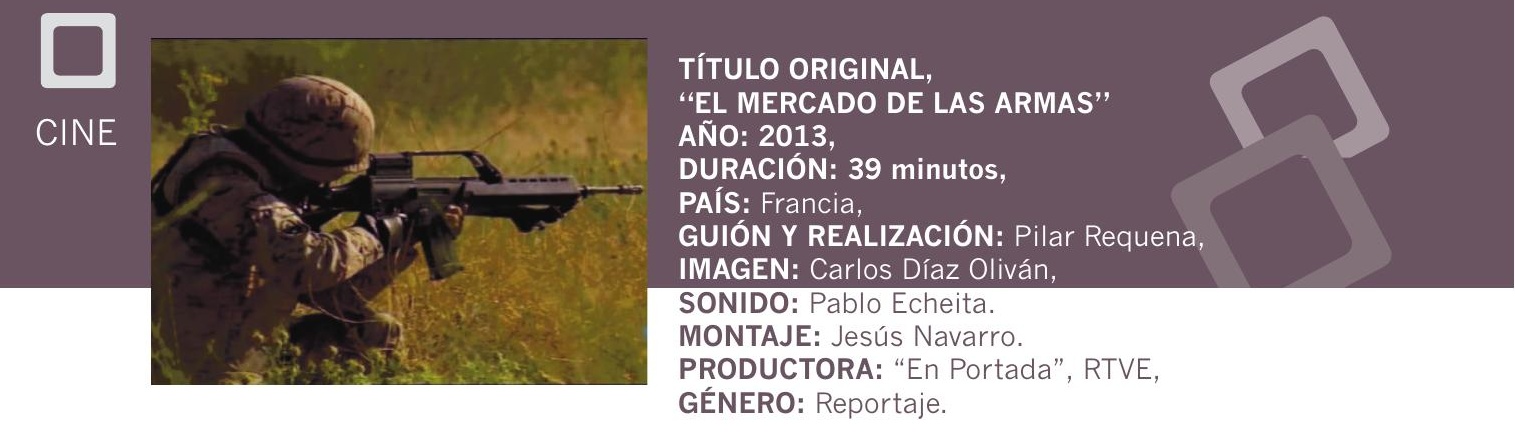

\title{
El mercado de las armas
}

El reportaje inicia con la experiencia de Jean de Tonquedac, quién fue un comerciante de armas que trabajó para varias empresas francesas y conoció de primera mano sobre las comisiones y sobornos que se hacen, a los implicados en negocios de ésta índole. Tonquedac señala que para estos comerciantes, su pago representa un porcentaje del total de la venta; asimismo identifica distintos proveedores, entre ingleses, alemanes, franceses e italianos.

En el mundo hay más de 650 millones de armas pequeñas y ligeras, la mitad en manos de civiles. En el tráfico ilegal de armas las principales áreas de interés ahora están en Oriente; en términos de violencia urbana están: Sudamérica, América Central y México, que son extremadamente importantes, ya que se ve el aumento de la cantidad de armas de estilo militar en manos del crimen organizado transnacional y organizaciones de narcotráfico (cárteles).

La sociedad civil pidió a la Organización de las Naciones Unidas (ONU), regular el comercio de armas. Es así como el 02 de abril de 2013 la ONU aprobó el Tratado de Comercio de Armas con 154 votos; 23 abstenciones, Rusia y China entre ellas, 3 en contra siendo: Irán, Siria y Corea del Norte. Este tratado entrará en vigencia cuando los 50 primeros Estados lo firmen y entrará en vigor 90 días después de su ratificación. Hasta la fecha, ni China ni Rusia han firmado el tratado. Alemania, Francia y el Reino Unido, lo firmaron el 3 de junio y Estados Unidos el 25 de septiembre de 2013. Este tratado se aplicará a armamento convencional como carros de combate, sistema de artillería de gran calibre, aeronaves de combate, helicópteros de ataque, barcos de guerra, misiles y armas pequeñas y ligeras.

El negocio de la armas mueve 50.000 millones de euros al año; en 2011 supuso un gasto de 310.000 millones de euros, mueve 640 millones de armas y 12.000 millones de balas en el mundo al año, dos por cada habitante del planeta. En más del $60 \%$ de las violaciones de derechos humanos documentadas por Amnistía Internacional en una década, se utilizaron armas pequeñas y ligeras. En muchos casos, por disparos del fusil de asalto AK-47, más conocido por el nombre de su inventor, Kalashnikov.

Entre los países más afectados están África y América Central. Sobre todo con armas ligeras y pistolas. Entre los seis grandes países exportadores de armas están: Estados Unidos de Norte América, Alemania, China, Francia, Reino Unido y Rusia; quienes suministran cerca de las tres cuartas partes del valor de las armas 
que hay en el mundo. Conscientes de que es imposible acabar con el tráfico de armas, lo que se busca es regular el tráfico ilícito, promover la paz y la seguridad y reducir el sufrimiento humano. Las armas pueden salir de forma legal de los países exportadores, pero una parte termina en guerras, en manos de niños soldados, y donde impera la violencia y se violan los derechos humanos.

De las empresas militares, 75 de las 100 primeras son originarias de Estados Unidos y de países de la Unión Europea. En Rusia, la industria militar está en manos del Estado. La casi totalidad de industrias de armamento tienen fuertes lazos con la política y los gobiernos, y a menudo se usan como una pieza más de la política exterior. Son estos países productores quienes a través de su mismo jefe de Estado, Ilevan un paquete de lo que hay en venta: Aviones, tecnología atómica, etc. Las armas van por rutas seguras y el dinero se paga en cuentas bancarias oscuras.

La distribución global del gasto militar en 2012 fue: Estados Unidos de Norte América con el 39\%, China con el 9,5\%, Rusia con el 5,2\%, Reino Unido con el 3,5\%, Japón con el 3,4\%, y otros países con el 21,2\%. El restante 12,8\% corresponde al resto del mundo. La cuarta parte del gasto mundial corresponde a 15 Estados entre los que están: Francia (3,4\%), Arabia Saudí (3,2\%), India (2,6\%), Alemania (2,6\%), Italia (1,9\%), Brasil (1,9\%), Corea del Sur (1,8\%), Australia $(1,5 \%)$, Canadá $(1,3 \%)$, Turquía (1\%), y España (1\%).

La distribución por regiones se sitúa así: América del Norte (40\%), América Latina (4\%), Europa (24\%), Oriente Medio (8\%), Asia y Oceanía (22\%) y África (2\%). EI gasto mundial es de 1, 2 billones de euros.

Este reportaje refleja una clara realidad de lo que pasa alrededor del mundo de los traficantes, el cómo operan con compañías y comerciantes relacionados con ejércitos, gobiernos, e incluso con servicios secretos; que van entre comisiones y sobornos dónde existen cuentas bancarias oscuras. Para los traficantes no hay arrepentimientos, remordimientos ni deudas morales, se afirma. El reportaje sostiene que es una paradoja que la venta de armas la realicen países occidentales a países que no cumplen sus propios estándares de democracia y derechos humanos.

Sinopsis a cargo de Yesenia Elizabeth Delgado Hernández Bibliotecóloga y documentalista Centro de Investigación Científica (CINC-ANSP) 